\title{
STUDI PERKEMBANGAN WILAYAH DAN DAYA DUKUNG LINGKUNGAN KEPARIWISATAAN DI WILAYAH YOGYAKARTA UTARA
}

\author{
Muhamad dan M. Baiquni \\ Program Studi Kajian Pariwisata \\ Sekolah Pascasarjana Universitas Gadjah Mada \\ Email: memet_andra@yahoo.com dan Email: baiquni99@gmail.com dan baiquni@lead.or.id
}

Chafid Fandeli

Fakultas Kehutanan Universitas Gadjah Mada

\begin{abstract}
The growth of tourist regions often indicates a decline of the environmental carrying capacity, including the conflict regarding the use of space and its carrying capacity. The uncontrolled spatial growth and resources use is the result of the increasingly development-oriented policy which cause damage to environmental functions. Consideration of the use of space and natural resources advantage is needed in order to properly consider the issue of carrying capacity. Research is needed to define the proper use of traffic signals in connection with the above problem; it is alsoimportant to analyze the region's carrying capacity, which can define its maximum tolerance and flexibility of capacity. The long-term purpose is to improve tourists' satisfaction with the area. There are (2) two variables considered: (1) the regional growth; (2) the ecological carrying capacity. The research sample consists of four villages in the Pakem region (Kaliurang area) and Merapi Volcano National Park (TNGM), DIY.
\end{abstract}

\section{Keywords: The Region Growth, The Ecology Carrying Support, Tourism Region}

\begin{abstract}
ABSTRAK
Perkembangan wilayah kepariwisataan seringkali diindikasikan menurunkan daya dukung lingkungan, termasuk terjadinya konflik penggunaan ruang dan daya dukungnya. Perkembangan wilayah dan sumber daya alam yang tidak terkendali merupakan akibat meningkatnya kebijakan pembangunan sehingga dapat menyebabkan kerusakan fungsi lingkungan beserta daya dukung, terutama daya dukung fisik, dan daya dukung ekologis. Perlunya pemanfaatan ruang dan sumber daya alam secara komprehensif dengan mempertimbangkan daya dukung. Oleh karena itu, diperlukan penelitian untuk menentukan rambu-rambu pengaman berkenaan dengan masalah tersebut. Pada sisi yang lain, tingkat kenyamanan para wisatawan juga akan berkurang karena terjadi kepadatan yang tinggi. Untuk itu, perlu dilakukan analisis daya dukung kawasan yang dapat menentukan batas toleransi dan kelenturan kapasitas yang masih memungkinkan secara fleksibel. Tujuan jangka panjangnya adalah terpenuhinya kepuasan pengunjung secara berkelanjutan di kawasan tersebut. Untuk memantapkan implementasi tujuan jangka panjang ini, maka ditetapkan fokus tema dengan topik studi daya dukung kepariwisataan di wilayah Yogyakarta bagian Utara. Sampel penelitian terdiri dari empat wilayah desa di Kecamatan Pakem (Kawasan Kaliurang) dan Taman Nasional Gunung Merapi Provinsi Daerah Istimewa Yogyakarta. Untuk menjawab permasalahan di atas terdapat dua variabel, yaitu (1) perkembangan wilayah, (2) daya dukung ekologis. Sampel penelitian terdiri dari
\end{abstract}


wilayah desa di Kecamatan Pakem (Kawasan Kaliurang) dan Taman Nasional Gunung Merapi (TNGM) Daerah Istimewa Yogyakarta.

Kata Kunci:Perkembangan: ilayah,' aya dukung (kologi, : ilayah. epariwisataan

\section{PENGANTAR}

Tekanan secara fisik di wilayah Yogyakartabagian utara adalah pembangunan yang tidak memperhatikan fungsi lingkungan. Hal ini diindikasikan dengan akibat kerusakan dan menurunya kualitas lingkungan, baik secara fisik maupun ekologis karena mempraktikkan pola pengelolaan kawasan konservasi yang tidak memperhitungkan daya dukung ekologinya.

Berbagai konflik dan potensi ancaman pembangunan kepariwisataan merupakan kendala utama di dalam pembangunan terkait dengan peran dan fungsi wilayah di Yogyakarta bagian utara. Potensi dan ancaman antara lain berasal dari tekanan penduduk di wilayah Yogyakarta bagian utara yang diperkirakan akan melakukan konversi lahan, kegiatan kepariwisataan, dan permukiman (Douglas, 1991 dalam Muta'ali, 1997). Konflik lain adalah pengelolaan yang belum dilaksanakan secara optimal, terutama aspek tata lingkungan dan pengelolaan kegiatan kepariwisataan (Baiquni, 1996 dan Sutikno, 2006).

Aspek kegiatan kepariwisataan dikritik sebagai pengeksploitasi, lingkungan, dan dituduh hanya sebagai pengejar keuntungan finansial pasar tanpa meningkatkan kapasitas pengelolaan lingkungan dan tanpa memperhitungkan kemungkinan pengaruhnya terhadap daerah sekitar, lingkungan, dan masyarakatnya (Hasanah, 2004). Pendapat di atas mengindikasikan adanya berbagai dampak negatif terhadap komponen daya dukung lingkungan.

Dampakini terjadi karena benturan fungsi komponen pembangunan antara ekologi dan ekonomi. Jika pertimbangan ekologi lebih kuat, pembangunan terasa lemah, dan lamban. Akan tetapi, jika pertimbangan ekonomi ditekankan, maka terjadi eksploitasi yang mempercepat berkurangnya kualitas dan kuantitas sumber daya. Tanpa memberikan kesempatan terhadap sumber daya lingkungan tersebut untuk mendaur ulang hidupnya, langkah kompromi atas keduanya merupakan jalan tengah yang baik.

Terdapat beberapa faktor lain dari dampak di atas yang menjadi permasalahan secara ekologis, yaitu tingkat perkembangan wilayah yang tinggi di wilayah ini. Permasalahan lain adalah adanya jumlah kunjungan wisatawan yang tinggi secara langsung maupun tidak langsung berakibat pada gangguan ekosistem lingkungan, bahkan dapat merusak lingkungan tersebut. Permasalahan pada tingkat kenyamanan para wisatawan juga akan berkurang apabila terjadi kepadatan yang tinggi. Oleh karena itu, perlu dilakukan kajian tentang daya dukung kawasan sebagai batas penentu toleransi kapasitas yang masih dimungkinkan secara fleksibel.

Terkait dengan kajian daya dukung kawasan (carrying capacity), maka analisis nantinya lebih difokuskan pada kawasan yang menjadi pusat kunjungan. Adapun pada kawasan yang belum menghasilkan kunjungan yang signifikan, akan digunakan hasil analisis kawasan yang menjadi pusat kunjungan. Hasil analisis pada pusat kunjungan akan diasumsikan sama untuk membatasi jumlah pengunjung pada kawasan yang belum menghasilkan kunjungan secara signifikan. Asumsi ini dapat difungsikan pada masa yang akan datang dan tahapan berikutnya khususnya bila kawasan yang belum dikunjungi tersebut telah sukses sebagai daerah tujuan wisata dan berhasil dipromosikan.

\section{Perkembangan Wilayah}

Kegiatan rekreasi secara keruangan akan membentuk perembetan tata guna lahan yang dapat mempengaruhi perkembangan wilayah. Perkembangan wilayah akibat perembetan tersebut dapat diklasifikasikan menjadi 
tiga, yaitu (1) perkembangan konsentris, (2) perkembangan meloncat, dan(3) perkembangan memanjang. Perkembangan konsentris merupakan perembetan kenampakan fisik yang terjadi pada semua sisi urban built land dan membentuk kesatuan yang kompak. Perkembangan meloncat merupakan perembetan kenampakan fisikal yang terjadi secara sporadis di daerah pinggiran kota, bersifat tidak menyatu dengan kenampakan kekotaan dan melewati lahan pertanian. Perkembangan memanjang merupakan perembetan kenampakan yang terjadisepanjang jalur transportasi atau jalur-jalur memanjang lainnya (Yunus, 2006).

Perkembangan daya tarik wisata dapat memicu perkembangan wilayah di sekitarnya, termasuk di dalamnya desa-desa. Hal tersebut sangat dimungkinkan karena perencanaan pengembangan pariwisata yang berkaitan dengan kewilayahan dilakukan melalui pusat pertumbuhan (growth center) (Yunus, 2006 dan Maryani, 2004). Perencanaan pembangunan ini difokuskan pada pembentukan pusatpusat pertumbuhan dalam suatu wilayah pengembangan tertentu (Yunus, 2001 dan sutaryono, 2007)..

Pusat pertumbuhan (growth center) dapat diartikan dengan dua cara, yaitu secara fungsional dan secara geografis. Secara fungsional, pusat pertumbuhan merupakan suatu lokasi konsentrasi kelompok usaha atau cabang industri karena sifat hubungannya memiliki kedinamisan sehingga mampu menstimuli kehidupan ekonomi, baik ke dalam maupun ke luar daerah belakangnya/hinterland. Secara geografis, pusat pertumbuhan merupakan suatu lokasi yang banyak memiliki fasilitas dan kemudahan sehingga menjadi pusat daya tarik (pole of attraction), yang menyebabkan berbagai macam usaha tertarik untuk berlokasi di tempat tersebut dan masyarakat datang untuk memanfaatkan fasilitas yang ada di lokasi tersebut (Jayadinata, 1986 dan Sutaryono, 2007).

\section{Daya Dukung Lingkungan}

Produk utama pariwisata adalah lingkungan itu sendiri (Soemarwoto, 2004). Dengan mengadaptasi UU No. 23 Tahun 1997 bahwa daya dukung kawasan pariwisata merupakan kemampuan tertentu suatu kawasan untuk menerima wisatawan. Pengertian daya dukung kawasan adalah kemampuan tertentu pada suatu daerah untuk menerima wisatawan atau jumlah wisatawan maksimal yang dapat memanfaatkan suatu kawasan tanpa menimbulkan penurunan kualitas lingkungannya (Sumarwoto, 1993). Hal yang mempengaruhi daya dukung kawasan pariwisata salah satunya adalah faktor lingkungan biofisik lokasi wisata tersebut. Selain faktor fisik, daya dukung kawasan pariwisata juga berkaitan dengan faktor psikologis wisatawan. Secara umum, untuk kawasan pegunungan yang memiliki hawa sejuk rata-rata wisatawan mencari nilainilai keheningan, jauh dari hiruk-pikuk polusi suara, dan rendahnya tingkat kepadatan manusia. Semuanya ini merupakan nilai dari sebuah kenyamanan untuk berwisata (Soemarwoto, 2004). Untuk itu, perencanaan pengembangan pariwisata haruslah memperhatikan daya dukung kawasan.

Pembangunan wilayah destinasi serta dari kualitas objek daerah tujuan wisata yang berlebihan dapat menyebabkan iritasi/gangguan terhadap wisatawan dan lingkungan, terutama kawasan konservasi (Fandeli dan Muhamad, 2009). Penelitian Doxey (1975), Prosser (1994), Cater \& Lowman, (1994) dalam Fandeli (2005) menyebutkan bahwa dalam akhir proses gangguan tersebut, yaitu lingkungan yang berubah tidak dapat dipulihkan dan seluruh sumber daya berubah, sehingga kebutuhan pariwisata juga akan berubah. Akhir proses gangguan tersebut tidak hanya pada wilayah, tetapi berpengaruh terhadap wilayah dan lingkungan sekitarnya secara lebih luas. IUCN memberi jaminan perlindungan terhadap lokasi untuk berwisata yang ditentukan oleh 
Tabel 1.

Aspek Perlindungan terhadap Lokasi Wisata

\begin{tabular}{lll}
\hline No & $\begin{array}{c}\text { Aspek } \\
\text { Perlindungan }\end{array}$ & \multicolumn{1}{c}{ Penjelasan } \\
\hline 1 & Daya dukung & $\begin{array}{l}\text { Dengan mengadaptasi dari UU No. 23 Tahun 1997: daya dukung kawasan } \\
\text { pariwisata merupakan kemampuan tertentu suatu kawasan untuk menerima } \\
\text { wisatawan. Daya dukung ini merupakan alat kontrol peringatan dini terhadap } \\
\text { kemampuan area untuk mendukung jumlah wisatawan. }\end{array}$ \\
& Tekanan terhadap & $\begin{array}{l}\text { Aspek ini merupakan dampak dari kumpulan ukuran yang disebabkan oleh aktivitas } \\
\text { dan kedatangan wisatawan. } \\
\text { area }\end{array}$ \\
Kemenarikan & $\begin{array}{l}\text { Merupakan kualitas dari objek dan daya tarik wisata yang dapat berubah dari waku } \\
\text { ke waktu. }\end{array}$ \\
\hline
\end{tabular}

Sumber: Dari Berbagai Sumber

tiga aspek seperti ditampilkan pada tabel 1 berikut di bawah ini.

Tabel di atas menggambarkan beberapa pendekatan tentang cara perlindungan ODTW (Objek Daya Tarik Wisata) dengan menentukan daya dukung objek wisata. Daya dukung lingkungan adalah kemampuan ODTW untuk mendukung/memenuhi kebutuhan sejumlah wisatawan. Angka ini dipergunakan sebagai pedoman menetapkan jumlah wisatawan yang dapat didukung ODTW agar tidak terjadi kerusakan kawasan. Terdapat tiga macam cara perhitungan daya dukung dan ketiganya dapat dipergunakan untuk menetapkan jumlah wisatawan yang boleh masuk kawasan, yaitu daya dukung fisik, daya dukung wilayah/ kawasan/tempat wisata, dan daya dukung di bidang kepariwisataan (Mowforth dan Munt, 1998 dan Douglass, 1975).

Beberapa contoh daya dukung kawasan wisata merupakan bagian dari kajian daya dukung karena terkait dengan populasi yang mendukung kelangsungan kehidupan di alam. Pengertian daya dukung menurut konsep ekologi adalah jumlah maksimum individu/unsur hayati yang masih dapat dijamin hidup dengan baik pada suatu kondisi lingkungan, sedangkan definisi daya dukung tempat wisata adalah jumlah wisatawan yang menggunakan suatu areal untuk berwisata, yang masih dapat didukung oleh areal tersebut (Colinvaux, 1986 dan Douglass 1975). Hal tersebut ditandai kualitas wisata sehingga keserasian dapat terjaga (Fandeli dan Muhammad, 2007). Secara operasional penggunaan konsep daya dukung di bidang kepariwisataan didefinisikan oleh ahli lingkungan sebagai kemampuan objek wisata alam untuk dapat menampung jumlah wisatawan pada luas dan satuan waktu tertentu (Soemarwoto, 1988).

Pembangunan wilayah kepariwisataan pada dasarnya melihat ketersediaan objek, fasilitas, dan pelayanan pariwisata (Pearce, 1989). Kebutuhan ruang dan lingkungannya merupakan bagian fasilitas atau service bagi wisatawan (Gunn, 1994). Wisatawan dibedakan menjadi dua berdasarkan kategori wisatawan sesuai dengan jarak yang ditinggalkan dari tempat asal sebagai berikut: (1) wisatawan yang berasal dari urban ke sub-urban (urban and urban fringe) yaitu jarak kurang dari 40 mil dari tempat tinggalnya; (2) wisatawan yang berakhir pekan (the weekend use zone, yaitu jarak dengan radius antara 40 mil hingga 120 mil, menurut Standard Metropolitan Statistical Areal (Douglass, 1975).

Beberapa faktor penting sebagai penentu daya dukung adalah perhitungan daya tampung kawasan berdasarkan data jumlah wisatawan yang tercatat dalam statistik jumlah kunjungan per-bulan. Pada kegiatan rekreasi tentunya wisatawan membutuhkan prasarana, maka variabel prasarana wisata juga akan dianalisis. Faktor daya dukung 
pariwisata sangat tergantung pada beberapa aspek yaitu kondisi lingkungan, jumlah, dan perilaku wisatawan yang akan berpengaruh terhadap keserasian wilayah (Fandeli dan Muhamad, 2009).

\section{PEMBAHASAN}

Posisi strategis Yogyakarta bagian utara yang terletak di antara Provinsi DIY dan Jawa Tengah menjadikannya sebagai channel untuk aktivitas pariwisata DIY-Jawa Tengah. Bandara Adisutjipto berada di Kabupaten Sleman mempermudah akses wisatawan ke DIY-Jawa Tengah, khususnya Kabupaten Sleman. Kemudahan akses ini menjadikan Kabupaten Sleman sebagai pusat pergerakan dari aktivitas kepariwisataan.

Peluang ini ditangkap oleh para pelakupelaku pariwitasa di Kabupaten Sleman dengan layanan wisata berupa pengembangan destinasi wisata, penyediaan sarana prasarana wisata, dan lain-lain. Kegiatan kepariwisataan di wilayah Yogyakarta Utara mengalami perkembangan yang pesat seiring dengan perhatian pemerintah daerah terhadap sektor kepariwisataan. Hal ini berdampak pada jumlah kunjungan wisatawan terhadap sebaran objek-objek dan daya tarik wisata (Tabel 2) di bawah ini.

Jumlah pengunjung per-bulan pada wilayah ODTW di wilayah Yogyakarta bagian utara secara terinci ada pada tabel 1 dan tabel 2 merupakan data perolehan retribusi dari sektor pariwisata di Yogyakarta bagian utara. Destinasi wisata yang potensial, antara lain berupa potensi budaya yang terdiri dari budaya, wisata alam, upacara adat, dan tradisi budaya di wilayah Yogyakarta bagian utara. Destinasi/objek wisata di Kabupaten Sleman diklasifikasikan menjadi wisata alam, candi, museum, pedesaan, pendidikan, belanja, kuliner, dan alternatif.

Berdasarkan hasil analisis di atas, diketahui bahwa konsentrasi pengunjung (pusat kunjungan) berada pada beberapa kawasan tertentu. Konsentrasi kunjungan tersebut meliputi: (1) kawasan wisata Kaliurang, (2) lava tour, (3) desa wisata. Berdasarkan hasil observasi ini, berikut akan ditampilkan rekapitulasi data kunjungan pada bulan kunjungan. Rekapitulasi data kunjungan merupakan data sekunder tahun terakhir (2007) yang diperoleh dari Dinas Pariwisata, Seni, dan Budaya pemerintah setempat. Data sekunder yang diperoleh akan menjelaskan tentang jumlah penerimaan setoran dari kunjungan wisatawan Nusantara dan Mancanegara.

\section{Potensi dan Perkembangan Wilayah Yogyakarta Bagian Utara}

Analisis dan pembahasan untuk melihat potensi dan perkembangan pembangunan kepariwisataan di wilayah Yogyakarta bagian utara dinilai berdasarkan beberapa variabel atau indikasi yang merupakan wujud komponen wilayah beserta lingkungan dengan z-score periode up date 2006-2008. Komponen potensi perkembangan wilayah di dalam penelitian dinilai berdasarkan lima variabel atau indikator yang merupakan pertumbuhan ataupun perubahan dari nilai $z$ score masing-masing indikator dari skala waktu yang berbeda.

Indikator potensi dan perkembangan wilayah tersebut adalah indeks komposit yang akan dianalisis secara berurutan. Berdasarkan variabel dan indikator tersebut, diperoleh sampel penelitian (Lima wilayah desa di Kecamatan Pakem) Sampel tersebut merupakan kawasan wisata yang terbentuk pada masa penjajahan Belanda dan berada di sekitar kawasan Taman Nasional Gunung Merapi Provinsi Daerah Istimewa Yogyakarta.

Potensi perkembangan wilayah yang tinggi terjadi di desa Pakembinangun dan Hargobinangun memiliki potensi wilayah cukup tinggi karena merupakan kawasan wisata yang sudah terbentuk lama. Wilayah Pakembinangun dan Hargobinangun merupakan inti pengembangan kawasan Gunung Merapi. Komponen dari 5 (lima) 
Tabel 2.

Pengunjung Objek dan Daya Tarik Wisata di Kabupaten Sleman bagi Wisatawan Asing Tahun 2007

\begin{tabular}{|c|c|c|c|c|c|c|c|c|c|c|c|c|c|}
\hline $\begin{array}{c}\text { Jenis } \\
\text { wisata }\end{array}$ & $\begin{array}{l}\text { Jan } \\
(\%) \\
\end{array}$ & $\begin{array}{l}\text { Feb } \\
(\%) \\
\end{array}$ & $\begin{array}{c}\text { Maret } \\
(\%)\end{array}$ & $\begin{array}{c}\text { April } \\
(\%)\end{array}$ & $\begin{array}{c}\text { Mei } \\
(\%)\end{array}$ & $\begin{array}{l}\text { Jun } \\
(\%)\end{array}$ & $\begin{array}{l}\text { Juli } \\
(\%)\end{array}$ & $\begin{array}{l}\text { Ags } \\
(\%)\end{array}$ & $\begin{array}{c}\text { Sept } \\
(\%)\end{array}$ & $\begin{array}{l}\text { Okt } \\
(\%)\end{array}$ & $\begin{array}{c}\text { Nov } \\
(\%)\end{array}$ & $\begin{array}{l}\text { Des } \\
(\%)\end{array}$ & $\begin{array}{c}\text { Jumlah } \\
(\%)\end{array}$ \\
\hline Candi & 83.37 & 90.06 & 81.04 & 86.59 & 83.51 & 80.49 & 80.67 & 84.21 & 85.88 & 83.63 & 88.88 & 78.46 & 66.10 \\
\hline Wis alam & & & & & & & & 2.62 & & & & & \\
\hline Museum & 1.45 & 1.40 & 1.23 & 2.16 & 1.28 & 1.31 & 2.69 & 1.08 & 0.96 & 4.05 & 2.36 & 10.57 & 1.93 \\
\hline Ds wisata & 4.75 & 1.61 & 10.05 & 2.34 & 0.50 & 1.88 & 0.43 & 1.58 & 0.11 & 0.21 & 1.96 & 2.97 & 22.49 \\
\hline Atraksi & 4.02 & 3.61 & 3.05 & 4.83 & 8.98 & 11.42 & 13.23 & 10.51 & 8.89 & 7.35 & 3.89 & 4.62 & 6.36 \\
\hline Total & 100 & 100 & 100 & 100 & 100 & 100 & 100 & 100 & 100 & 100 & 100 & 100 & 100 \\
\hline
\end{tabular}

Sumber : Dinas Pariwisata Seni dan Budaya Kabupaten Sleman (dimodifikasi)

Tabel 3.

Pengunjung Obyek dan Daya Tarik Wisata di Kabupaten Sleman Bagi Wisatawan Domestik Tahun 2007

\begin{tabular}{lccccccccccccc}
\hline \multicolumn{1}{c}{$\begin{array}{c}\text { Jenis } \\
\text { wisata }\end{array}$} & $\begin{array}{c}\text { Jan } \\
\mathbf{( \% )}\end{array}$ & $\begin{array}{c}\text { Feb } \\
(\mathbf{\%})\end{array}$ & $\begin{array}{c}\text { Maret } \\
(\mathbf{\%})\end{array}$ & $\begin{array}{c}\text { April } \\
(\mathbf{\%})\end{array}$ & $\begin{array}{c}\text { Mei } \\
(\mathbf{\%})\end{array}$ & $\begin{array}{c}\text { Jun } \\
(\%)\end{array}$ & $\begin{array}{c}\text { Juli } \\
(\mathbf{\%})\end{array}$ & $\begin{array}{c}\text { Ags } \\
(\mathbf{\%})\end{array}$ & $\begin{array}{c}\text { Sept } \\
(\%)\end{array}$ & $\begin{array}{c}\text { Okt } \\
(\%)\end{array}$ & $\begin{array}{c}\text { Nov } \\
(\%)\end{array}$ & $\begin{array}{c}\text { Des } \\
(\%)\end{array}$ & $\begin{array}{c}\text { Jumlah } \\
(\%)\end{array}$ \\
\hline Candi & 36.41 & 33.39 & 33.22 & 33.74 & 32.64 & 37.37 & 42.63 & 32.57 & 32.49 & 41.72 & 34.56 & 51.43 & 36.87 \\
Wis alam & 42.08 & 49.13 & 49.48 & 43.48 & 39.93 & 31.53 & 40.10 & 56.17 & 57.18 & 42.97 & 50.03 & 33.49 & 44.54 \\
Museum & 20.06 & 16.76 & 15.71 & 21.89 & 25.29 & 28.83 & 14.28 & 7.69 & 8.01 & 14.02 & 12.99 & 13.87 & 16.75 \\
Ds wisata & 0.03 & 0.06 & 0.03 & 0.03 & 0.04 & 0.02 & 0.04 & 0.10 & 0.06 & 0.05 & 0.01 & 0.03 & 0.04 \\
Atraksi & 1.41 & 0.67 & 1.57 & 0.86 & 2.10 & 2.25 & 2.94 & 3.47 & 2.26 & 1.24 & 2.41 & 1.18 & 1.80 \\
\hline Total & 100 & 100 & 100 & 100 & 100 & 100 & 100 & 100 & 100 & 100 & 100 & 100 & 100 \\
\hline
\end{tabular}

Sumber : Dinas Pariwisata Seni dan Budaya Kabupaten Sleman (dimodifikasi)

indikator penilai memiliki pola yang mempunyai kevariasian terhadap potensi perkembangan wilayah. Indikator tersebut antara lain adalah kependudukan dan aksesibilitas wilayah umumnya tersebar secara merata dan mempengaruhi indeks potensi wilayah tersebut, seperti terlihat pada tabel di bawah ini.

Berdasarkan analisis z-score di atas menunjukkan beberapa kevariasian potensi perkembangan wilayah dengan indeks potensi perkembangan wilayah yang dipengaruhi oleh faktor kondisi lingkungan dan geografis wilayah. Beberapa faktor tersebut antara lain sebagai beriku: infastruktur pembangunan (jalur transportasi wilayah dan kepariwisataan), tata guna lahan (proporsi lahan pertanian, kepadatan lingkungan, konversi lahan pertanian menjadi lahan terbangun), kependudukan (kepadatan penduduk, dan pertumbuhan penduduk).
Infrastruktur wilayah meliputi panjang jalan dengan kelas jalan, jarak terdekat dari dan ke sub-sub wilayah, struktur jaringan jalan semua bernilai (+) artinya komponen infrastruktur sudah terbentuk, hanya wilayah desa Harjobinangun yang bernilai negatif $(-5,0469)$ karena terdapat beberapa segmen jalan yang belum teraspal dan kondisi yang kurang baik.

Indeks potensi perkembangan wilayah Kecamatan Pakem mempunyai indeks perkembangan yang positif, yaitu Wilayah Hargobinangun 0,3008, Wilayah Pakembinangun $(1,7167)$, dan Wilayah Purwobinangun0,3694.Sehingga wilayahPakem mempunyai indeks potensi perkembangan wilayah yang signifikan (dominan positif). Konversi lahan yang terjadi pada wilayah di Kecamatan Pakem tersebut didominasi oleh perubahan lahan untuk kegiatan kepariwisataan yaitu sarana dan prasarana pariwisata. Hampir 
$70 \%$ perubahan itu terjadi sejak lama. Pada saat ini penggunaan lahan dan konversi lahan di wilayah Kecamatan Pakem tidak dapat dilepaskan dari sejarah pembentukan wilayah tersebut (sejak zaman penjajahan Belanda)

Hasil analisis perkembangan wilayah menunjukan kevariasian terhadap penggunaan lahan dan konversi lahan. Konversi lahan yang terjadi terutama di wilayah Pakembinangun yang bernilai positif $(1,4892)$. Perubahan kevariasian di wilayah tersebut ditunjukan dengan adanya perubahan dan pengkonversian lahan seperti perubahan lahan pertanian menjadi lahan perkebunan, permukiman, dan fasilitas di wilayah desa lainnya.

Tingkat kevariasian di wilayah Kecamatan Pakem konversi lahan terbentuk dibeberapa kluster sedangkan lahan yang lain masih didominasi oleh lahan terbuka seperti sawah, kebun campuran, perkebunan, dan hutan. Walaupun lahannya masih terbuka dan luas, tetapi pemanfaatannya terbatas karena lereng yang terjal dan elevasinya tinggi.

Selanjutnya setelah analisis potensi perkembangan wilayah yang dievaluasi, maka sejauh manakah daya dukung kawasan untuk kepariwisataan yang meliputi: daya dukung kawasan, karena diwilayah Kecamatan Pakem ini mempunyai sebaran obyek dan daya tarik wisata yang mempunyai tingkat kunjungan yang tinggi baik wisatawan nusantara maupun wisatwan asing.

\section{Daya Dukung Kawasan Pariwisata.}

Beberapa faktor penting sebagai penentu daya dukung adalah perhitungan daya tampung kawasan berdasarkan data jumlah wisatawan yang tercatat dalam statistik jumlah kunjungan per-bulan (pada tabel 1 dan 2) dan pada saat musim liburan. Wisatawan membutuhkan prasarana wisata dan variabel prasarana wisata yang dianalisis dengan analisis daya dukung yang menitikberatkan pada daya tampung kawasan pariwisata guna kegiatan rekreasi (Fandeli dan Muhammad, 2009).

Analisis nilai daya tampung optimal merupakan data jumlah pengunjung perbulan, maka dari itu harus dicari berapa jumlah pengunjung tertinggi dan terendah yang selanjutnya dibagi dengan bulan perolehan data, sehingga dapat ditentukan kapasitas daya dukung berdasarkan jumlah pengunjung yang paling akhir.

Analisis daya tampung kawasan wisata, difokuskan pada proses asosiasi antara pembagian jumlah pengunjung dengan luasan optimal pemanfaatankawasan. Selanjutnya, dari angka tersebut dapat ditentukan daya tampung optimal dengan mekanisme pengurangan angka jumlah pengunjung dengan daya tampung maksimal. Beberapa variabel formula yang dipakai di dalam pendekatan ini sebagai berikut: daya tampung maksimal kawasan dan prasarana wisata (satuan orang/hektar) dan (satuan orang/meter persegi), jumlah

Tabel 3

Potensi Perkembangan Wilayah di Yogyakarta Bagian Utara.

\begin{tabular}{ccccccccc}
\hline No & Kec & Wilayah & $\begin{array}{c}\text { Kepa- } \\
\text { datan }\end{array}$ & $\begin{array}{c}\text { Infra- } \\
\text { struktur }\end{array}$ & $\begin{array}{c}\text { Peng \& } \\
\text { konversi } \\
\text { lhn }\end{array}$ & $\begin{array}{c}\text { Pertum- } \\
\text { buhan }\end{array}$ & Aksesibilitas & $\begin{array}{c}\text { Indeks potensi } \\
\text { wilayah }\end{array}$ \\
\hline & & & Zscore & Zscore & zscore & zscore & & \\
1 & Pakem & Candibinangun & $-0,4212$ & 0,1826 & $-1,0453$ & $-1,8024$ & 2,6590 & $-0,4273$ \\
2 & Pakem & Hargobinangun & $-0,9903$ & 2,3733 & $-0,0517$ & 0,4579 & $-1,4885$ & 0,3008 \\
3 & Pakem & Harjobinangun & $-0,1152$ & $-5,0469$ & 0,6726 & $-0,8337$ & 1,9314 & $-3,3917$ \\
4 & Pakem & Pakembinangun & 0,6134 & 2,6365 & 1,4892 & 0,4579 & $-0,5019$ & 1,7167 \\
5 & Pakem & Purwobinangun & $-0,7076$ & 0,9154 & 0,6337 & $-0,1879$ & $-0,2842$ & 0,3694 \\
\hline
\end{tabular}

Sumber: Analisis dan Olah Data, 2009 
wisatawan/bulan dan objek wisata yang menonjol, luas pemanfaatan optimal.

Apabila telah diketahui daya tampung optimal, maka dilanjutkan dengan mencari keputusan kapasitas daya tampung optimal dari angka jumlah kunjungan. Jumlah kunjungan ini merupakan data pengunjung dengan karakter angka per-bulan, maka harus dicari berapa jumlah pengunjung tertinggi dan terendah yang selanjutnya dibagi dengan bulan perolehan data. Dengan demikian dapat ditentukan kapasitas daya dukung berdasarkan jumlah pengunjung yang paling akhir. Adapun rumusnya sebagai berikut: Untuk mengimplementasi lebih jelasnya ditampilkan dalam bentuk tabulasi perhitungan daya tampung. Berdasarkan data sekunder terdapat pusat kunjungan terpusat pada empat objek daya tarik wisata, yaitu taman rekreasi Kaliurang, Taman Nasional Gunung Merapi (TNGM) Provinsi Daerah Istimewa Yogyakarta, Lava tour, dan desa wisata. Terdapat empat wilayah yang memiliki data jumlah pengunjung yang relatif cepat dan jumlah kunjungan bulan tertentu (masa liburan). Adapun objek daya tarik wisata lainnya bahwa menggunakan pendekatan asumsi jumlah pengunjung (diperoleh tahun 2007). Asumsi ini berdasarkan faktor kedekatan dengan lokasi obyek daya tarik wisata tersebut.

Terkait dengan hasil analisis keputusan yang diambil, maka akan dihasilkan melalui proses analisis ideal dengan kombinasi pada faktor etika kelenturan kebijakan lingkungan. Analisis ideal tersebut menghasilkan angka daya tampung pengunjung pada suatu kawasan, masih perlu dilanjutkan dengan tahap kelenturan. Tahap kelenturan ini merupakan mempertimbangan nilai tertinggi dan terendah pada bulan perolehan data, sehingga keputusan tidak menjadi kaku.

Analisis daya tampung optimal di atas adalah rekapitulasi data kunjungan pada beberapa wilayah desa wisata dan objek daerah tujuan wisata. Rekapitulasi data merupakan data sekunder tahun terakhir (2007-2008) yang diperoleh dari Dinas Pariwisata Seni dan Budaya di Pemerintah Kabupaten Sleman, sehingga kebutuhan area di dalam menampung kegiatan wisatawan yang berkunjung di wilayah tersebut dapat direncanakan terutama pusat-pusat kunjungan (konsentrasi kunjungan wisatawan).

Hasil analisis dan keputusan untuk kelenturan tersebut sebagai berikut: (1) Untuk kawasan Taman Rekreasi Kaliurang, diputuskan daya tampung optimal jumlah pengunjung: 6.638 orang/hektar/bulan. (2) Untuk kawasan wisata pengamatan Taman Nasional Gunung Merapi (Hutan wisata Kaliurang), diputuskan daya tampung optimal jumlah pengunjung: 7.029 orang/ hektar/bulan. (3) Untuk kawasan Lava Tour, diputuskan daya tampung optimal jumlah pengunjung: 6.638 orang/hektar/bulan. (4) Seluruh desa wisata yang terdapat di wilayah Pakem diputuskan daya tampung optimal, yaitu Desa Wisata Ngipiksari, Desa Wisata Sambi, Desa Wisata Srowulan, Desa Kaliurang Timur, dan Desa Turgo daya tampung optimal jumlah pengunjung: 7.045 rata-rata orang/hektar/bulan.

Dari hasil analisis di atas menunjukkan daya tampung optimal (keleluasaan) untuk berwisata mempunyai tingkat kelenturan yang tinggi di taman rekreasi Kaliurang, hutan wisata Kaliurang, kawasan Lava Tour, desa wisata, tingkat keserasian wilayah masih terjaga terutama kawasan wisata hutan, desa wisata, dan kawasan wisata Kaliurang terutama pada saat musim libur panjang pada bulan Juli dan Agustus. Untuk Taman Rekreasi Kaliurang dan Lava Tour mempunyai tingkat keleluasaan yang tinggi karena wilayah ini berada di kawasan penyedia jasa lingkungan yaitu Taman Nasional Gunung Merapi (TNGM) Provinsi DIY.

Analisis dan keputusan daya dukung pariwisata sangat tergantung pada beberapa aspek yaitu kondisi lingkungan, jumlah, dan perilaku wisatawan (Fandeli dan Muhamad, 
2009) yang akan berpengaruh terhadap keserasian wilayah sehingga hasil analisis kebutuhan dan daya tampung wisatawan dapat direncanakan, terutama pusat-pusat kunjungan (konsentrasi wisatawan) di wilayah Kecamatan Pakem secara keseluruhan. Untuk itu, dapat diilustrasikan dengan istilah kemampuan lahan karena masih dapat menjamin jumlah maksimum individu unsur hayati yang masih dapat dijamin hidup dengan baik pada suatu kondisi lingkungan (Sutikno, 2007; Colinvaux, 1986) dan daya dukung tempat wisata terhadap jumlah wisatawan yang menggunakan suatu areal untuk berwisata, masih dapat didukung oleh areal tersebut.

\section{SIMPULAN}

Berdasarkan hasil penelitian terhadap potensi perkembangan wilayah kepariwisataan dan daya dukung lingkungan kepariwisataan terlihat bahwa wilayah Yogyakarta bagian Utara sebagai penyedia jasa lingkungan kepariwisataan merupakan wilayah yang sangat potensial untuk dikembangkan dan direncanakan pada masa yang akan datang. Kondisi daya dukung wilayah yang masih tergolong tinggi dan mempunyai kelenturan memungkinkan untuk lebih dioptimalkan dan tetap berorientasi pada kelestarian fungsi lingkungan yang berkelanjutan dan berwawasan lingkungan.

\section{DAFTAR PUSTAKA}

Baiquni. M, 1996, "Fenomena Perkembangan Yogyakarta Utara", makalah disampaikan dalam diskusi ilmiah Manajemen Pengembangan Kawasan Utara Yogyakarta", 20 Desember 1996, BEM Fakultas Geografi UGM, Yogyakarta.

Colinvaux. P, 1986, Ecology, John Wiley dan Sons, New York.

Dauglas. RW, 1975, Forest Recreations, Second Edition, Pergamon Press Inc. New York.

Tabel 5.

Daya Tampung Wilayah di Wilayah Yogyakarta Bagian Utara

\begin{tabular}{clcccccc}
\hline \multirow{2}{*}{ No } & \multirow{2}{*}{ Objek Wisata } & Luas & \multicolumn{2}{c}{ Juli } & \multicolumn{2}{c}{ Agustus } & \multicolumn{1}{c}{$\begin{array}{c}\text { Kepts } \\
\text { (org/ha) }\end{array}$} \\
\cline { 2 - 6 } 1 & Hutan Wisata Kaliurang & 85 & 11.053 & 102.291 & 7.501 & 78.227 & 7.029 \\
2 & Tlogo Putri & 2 & 405 & 51.754 & 117 & 39.579 & 3.556 \\
3 & Pengamatan Merapi & 1,0 & 77 & 207 & 75 & 158 & 14 \\
4 & Bumi Perkemahan & 12 & 625 & 94.883 & 426 & 72.562 & 6.520 \\
5 & Htn Percbn Kaliurang & 10 & 1.105 & 93.157 & 750 & 71.242 & 6.401 \\
6 & Tlogo Nirmolo & 5 & 202 & 82.807 & 205 & 63.326 & 5.690 \\
7 & View Lava & 15 & 3.496 & 96.608 & 3.690 & 73.881 & 6.638 \\
8 & Panorama Vulkanik & 10 & 252 & 93.157 & 274 & 71.242 & 6.401 \\
9 & Sistem Pemantauan Merapi & 1,15 & 521 & 13.501 & 587 & 10.325 & 928 \\
10 & Air Panas (SPA) & 1,5 & 426 & 34.503 & 507 & 26.386 & 2.371 \\
11 & Wisata Trekking & 8 & 154 & 90.570 & 169 & 69.263 & 6.401 \\
13 & Tmn Rekrsi Kaliurang & 15 & 75.854 & 96.608 & 55.434 & 73.881 & 6.638 \\
14 & Museum Ulen Sentalu & 1,5 & 2.232 & 34.503 & 1.700 & 26.386 & 2.371 \\
15 & Desa Wisata Ngipiksari & 88 & 0 & 102.332 & 0 & 78.259 & 7.032 \\
16 & Desa Wisata Sambi & 95 & 71 & 102.419 & 200 & 78.325 & 7.038 \\
17 & Desa Wisata Srowulan, & 84,25 & 0 & 102.280 & 0 & 78.219 & 7.028 \\
18 & Desa Kaliurang Timur & 105 & 0 & 102.522 & 0 & 78.404 & 7.045 \\
29 & Desa Turgo & 96,29 & 30 & 102.433 & 62 & 78.336 & 7.039 \\
20 & Djumadil Kubro & 1,15 & 3.250 & 13.501 & 3.350 & 10.325 & 928 \\
\hline
\end{tabular}

Sumber: Analisis Peneliti, 2008 
Fandeli. C. dan Muhamad, 2009, Prinsip-prinsip Dasar Mengkonservasi Lanskap Gadjah Mada University Press, Yogyakarta.

Gunn C.A, 1994, Tourism Planning Basics. Concepts Cases, Third Edition. Taylor \& Francis Publisher.

Jayadinata. J.T, 1986, Tata Guna Tanah dalam Perencanaan Pedesaan Perkotaan dan Wilayah, Institut Teknologi Bandung, Bandung.

Kantor Kementrian Lingkungan Hidup, 1997, Undang-Undang Republik Indonesia Nomor 23 Tentang Pengelolaan Lingkungan Hidup (UNDANG-UNDANG PLH), Jakarta.

Lascurain. HC, 1990, Tourism, Eco-tourism, and Protecd Area, IUCN Protected Areas Programme, IV, World Congres on National Parks dan Protected Areas. Caracas, Venezuela, 10-21 Februari 1992.

Maryani. E, 2004, "Struktur Keruangan Pariwisata di Kawasan Inti Bandung Raya". Disertasi, Program Pascasarjana Universitas Gadjah Mada, (tidak diterbitkan) Yogyakarta.

Pemerintah Kabupaten Sleman, 2007, Data Monografi Kecamatan, Kecamatan Tempel, Semester Kedua, Sleman.
Soemarwoto, O, (penyunting) 2003, Menuju Jogja Provinsi Ramah Lingkungan Agenda 21 Pembangunan Pariwisata Berkelanjutan, Pemerintah Provinsi DIY, Yogyakarta. 1998, Ekologi Lingkungan Hidup dan Pembangunan, Djambatan, Jakarta.

Sutaryono, 2007, Dinamika Penataan Ruang dan Peluang Otonomi Daerah, Tugu Jogja Grafika, Yogyakarta.

Sutikno, 1995, "Environment Degradation of Urban Area on Fluvio Volcanic Plain (Case Study of Yogyakarta)" dalam The International Journal of Geography, Faculty of Geography, Gadjah Mada University, Yogyakarta.

Yunus H.S, 2006, "Problema Perkembangan Fisik kota, acuan khusus di daerah urban fringe", Makalah disampaikan dalam forum Seminar Nasional Mengenai Fenomena Perkembangan Fisik Kota, 14 Desember 2006, diselenggarakan oleh Jurusan Perencanaan Wilayah dan Kota, Fakultas Teknik Universitas Diponegoro. 